\title{
The Effect of Workplace Bullying and Job Satisfaction on Turnover Intention of Employee
}

\section{Ilfi Nurdiana}

Maulana Malik Ibrahim Islamic State University of Malang, Indonesia

\section{Leny Elyatin}

Maulana Malik Ibrahim Islamic State University of Malang, Indonesia

\section{Rini Safitri*}

Maulana Malik Ibrahim Islamic State University of Malang, Indonesia

rini.safitri@uin-malang.ac.id

${ }^{\star}$ Corresponding author

\begin{abstract}
A good environment can be formed through relationships between employees. The relationship between these employees will later have an effect on employee performance, it can be concluded that the relationship between employees is very important to be in the scope of a company organization. Workplace bullying is an act that should not exist in a company or organization. However, it cannot be denied that workplace bullying is now a phenomenon and a problem for companies. The existence of workplace bullying against employees will cause an employee to feel threatened and if there is constant eating it will cause the employee to have the intention to change jobs (turnover intention ) and looking for a new workplace out there, besides that workplace bullying also causes dissatisfaction dan decrease employee performance which will also disrupted company operations. This research uses quantitative research. Data analysis in this study used the PLS (Partial Least Square) analysis test. The population in this study were employees of the Amaris Hotel Surabaya and data collected using a questionnaire and the sample used in this study was a saturated sampling method. The results of this study indicate that workplace bullying has a positive and significant effect on turnover intention. And job satisfaction cannot moderate the relationship workplace bullying to turnover intention.
\end{abstract}

Keywords: Workplace Bullying, Turnover Intention, Job Satisfaction

\section{INTRODUCTION}

In every activity the company will never be separated from the role of resources: technology, machines, money and including humans themselves. All these components will be interrelated in order to achieve the company goals. An organization or company certainly requires professional and competent human resources so that the components in the company are related to each other. Sanjaya and Indrawati (2014), stated that a good working environment can be formed through relationships between employees. The relationship between these employees will affect the employees performance, it 
can be concluded that the relationship between employees is very important in the scope of a company organization.

With regard to the relationship between employees, the phenomenon of bullying or intimidation is currently being widely discussed in all circles. This does not rule out the possibility that there will be acts of intimidation or bullying in the workplace which will greatly affect employee performance. This bullying phenomenon is evidenced by a survey conducted by the workplace bullying Institute in America in 2017. He explained that $19 \%$ of Americans were victims of bullying and another $19 \%$ witnessed it. $61 \%$ are aware of abusive behavior in the workplace and 60.4 million people are affected by it and $70 \%$ of the perpetrators are men and $60 \%$ of the targets are women. This shows that in developed countries bullying occurs in the workplace. And the impact of bullying is very complex, the impact is not only felt by the victim but also the people around the victim of bullying. Nurul and Idha (2014), revealed that as many as 20 employee subjects in Gresik had experienced bullying in the workplace. In the study, the most frequent bullying was from colleagues or direct superiors. Responses to bullying also vary from silence, verbal protest or physical retaliation, resulting in a fight between the subject and the bullies.

Regarding the impact of bullying in the workplace, Said and Irma (2019) revealed that the act of bullying will decrease employee performance (Miner, Settles, Pratt-Hyatt and Brady, 2012. Psychological pressure, depression and (Nurul and Idha , 2014; Djamilah, Dijah, Iman, 2012; Fadlyanti 2017) will result in employees leaving the company and looking for a more comfortable place to work.

The high level of job satisfaction of an employee in a company will lead to good employee performance, and vice versa if the level of job satisfaction of an employee decreases it will cause an employee to intend to leave the company. As with the existence of workplace bullying or intimidation in the workplace, it will cause an employee's job satisfaction to decrease.

The occurrence of turnover intention will affect the company. This direct or indirect influence results in disruption of the company's operations. Not only that, the entry and exit of employees will also harm the company because the company has to think about the cost of recruiting employees again. Hasibuan (2007) expressed the desire to quit employees due to lack of job satisfaction in the company concerned, such as, low remuneration, getting a bad job, poor working environment, no promotion opportunities, unfair treatment (Toly, 2001) role conflict, locus of control, organizational change, job insecurity, organizational commitment, and organizational trust.

Amaris Hotel Surabaya often has employee turnover or turnover intention. Of course, this makes researchers interested and has the assumption that employee turnover at Amaris Hotel Surabaya is related to unpleasant actions at work or pressure and lifestyle 
demands that must be met in order to feel the same as other employees or here in after referred to as workplace bullying. The purpose of this study to explain the effect of workplace bullying to turnover intention, to explain Job satisfaction moderates the effect of workplace bullying on turnover intention.

\section{LITERATURE REVIEW}

\section{Workplace Bullying}

Bullying has received attention from researchers and managers because of the negative consequences associated with a work environment that is laden with negative and unreasonable treatment of some or many employees (Sims, Randi $L$ and Sun, Peng, 2011). Bullying at work is a serious loss of personal resources due to repeated loss of selfesteem, dignity and status (Srivastava, Shalini and Agarwal, Swati, 2020). Workplace bullying can be manifested through unreasonable actions with deadlines, undue workload, continuous monitoring of work, practical jokes, spreading gossip, insulting remarks and threats directed at the target (Rai and Agarwal, 2017; Yahya et al, 2012). According to Shalina and Dey (2019), this behavior can be categorized into intimidation, where bullying can be divided into two categories namely work-related bullying (unmanageable workload) and people (derogatory remarks). Bullying can be categorized into different types based on how it occurs in the organization, the five categories are (Shalina and Dey, 2019): (1) Threats to professional status (belittled and humiliated by victims) (2) Threats to personal position (humiliation, ridicule, intimidation) (3) Isolation (isolating the victim physically or socially) (4) Overwork (undue pressure and setting impossible deadlines (5) Destabilization (not giving credit when due or repeated error). In addition, according to Matthiesen and Einarsen (2010) there are several subtypes of bullying in the workplace, namely bullying related to disputes, bullying of predators, scapegoats, sexual harassment, humour-oriented bullying, work-related stalking, bullying of newcomers in the workplace, lawbreakers, and retaliation. Of course, bullying or oppression will have consequences for individuals and organizations. The consequences that will be experienced by individuals are anxiety, depression, negative emotions, open anger, sleep problems, and work fatigue (Shalina and Dey, 2019). While the consequences experienced by the organization are more absenteeism, lower task performance, decreased productivity, decreased employee morale, low organizational commitment, low employee satisfaction,

\section{Turnover intention}

Turnover intentionis an employee's cognitive response to certain organizational working conditions and the overall economic condition of a nation that stimulates an employee to look for a better alternative job and voluntarily leave the organization (Bhat et al, 2020). Intention to leave employees is a function of the organization and economic conditions of the nation. According to Memon et al (2017) there are three stages of 
withdrawal of thoughts of quitting work, the intention to look for a different job, and the intention to quit. then there are three types of turnover (Onyemah, et al, 2021) namely: functional and dysfunctional turnover, controlled and uncontrolled turnover, and voluntary and forced turnover.

\section{Job satisfaction}

A person's job satisfaction is the amount of job satisfaction (every aspect of the job) multiplied by the level of importance of the job (Pawirosumarto et al, 2016). Job satisfaction is a positive emotion that arises from the comfort of each employee when carrying out work (Sani, 2013). Job satisfaction describes the attitude of being happy or unhappy, satisfied or dissatisfied at work (Zainal et al, 2014) this depends on how employees perceive compatibility or conflict between desires and results (Pawirasumarto et al, 2016). There are several factors that affect job satisfaction, namely the content of supervision work, advancement opportunities, salary, working conditions, co-workers, organization and management (Sedarmayanti, 2017), supervisory relationships, internal organizational communication, and job design (Porter et al, 2016). Satisfaction can be increased or not depending on the rewards in accordance with the expectations, needs, and desires of employees (Zainal et al, 2014). There are three theories related to job satisfaction (Sedarmayanti, 2017), namely: (1) The theory of dissonance, calculates a person's job satisfaction by calculating the difference between something that should be and the perceived reality (2) The theory of justice, people feel satisfied or dissatisfied depending on whether there is or is not. whether or not justice in the situation (3) The theory of two factors, job satisfaction and dissatisfaction are two different things. Factors or situations needed as a source of job satisfaction consist of interesting work, challenges and opportunities for achievement. While dissatisfaction comes from salary or wages, supervision, interpersonal relationships, working conditions, and status.

\section{Workplace bullying affect turnover intention}

Research conducted by Shalini and Swati (2020) on a sample of 480 employees from the hospitality sector in India shows that Workplace Bullying is positively related to intention to leave. In addition, research conducted by Ahmad and Ahmad Kaleem (2019) on 627 Australian and Pakistani employees shows that exposure to workplace bullying triggers intention to move through negative effects on affective well-being across cultures or nationally.

\section{Job satisfaction moderates the effect of workplace bullying on turnover intention}

Research conducted by Sims and Sun (2011) on Chinese employees shows that there is a negative relationship between workplace bullying and job satisfaction and employee commitment. In addition, this study found that tension and satisfaction fully mediate the relationship between workplace bullying and employee intention to leave. This is 
supported by research conducted by Memon et al (2020) which found that training satisfaction and performance appraisal satisfaction were the main drivers of employee involvement in the workplace which in turn had a negative impact on employee turnover intention. One of the factors of job satisfaction is employee voice. Where employee voice is carried out with the aim of improving conditions and influencing individual relationships, this is supported by the two-factor theory that makes the relationship between individuals a factor of dissatisfaction. This is in line with the research conducted by Liang and Yeh (2019) which found that there was a significant relationship between voice behavior and workplace bullying and between employee voice and job satisfaction.

\section{METHODOLOGY}

This study uses a quantitative approach with an explanatory type, namely research that examines the hypothesized variables (Supriyanto \& Masyhuri, 2010). The location of this research was conducted at Amaris Hotel Surabaya. Jl. Taman Bintoro No.3, Dr. Soetomo, Tegalsari, Surabaya. The population used in this study were all employees of Amaris Hotel Surabaya. This study uses a saturated sampling method, which is a method that takes the entire population as a sample. This study uses primary and secondary data, primary data from this study were obtained directly from Amaris Hotel Surabaya employees by filling out questionnaires that had been distributed, while secondary data was obtained from the company through documentation or existing books and other information related to research.

\section{RESULTS}

\section{Structural Model (Inner Model)}

Testing of the inner model or structural model is carried out to see the relationship between the construct, significance value and R-square of the research model.

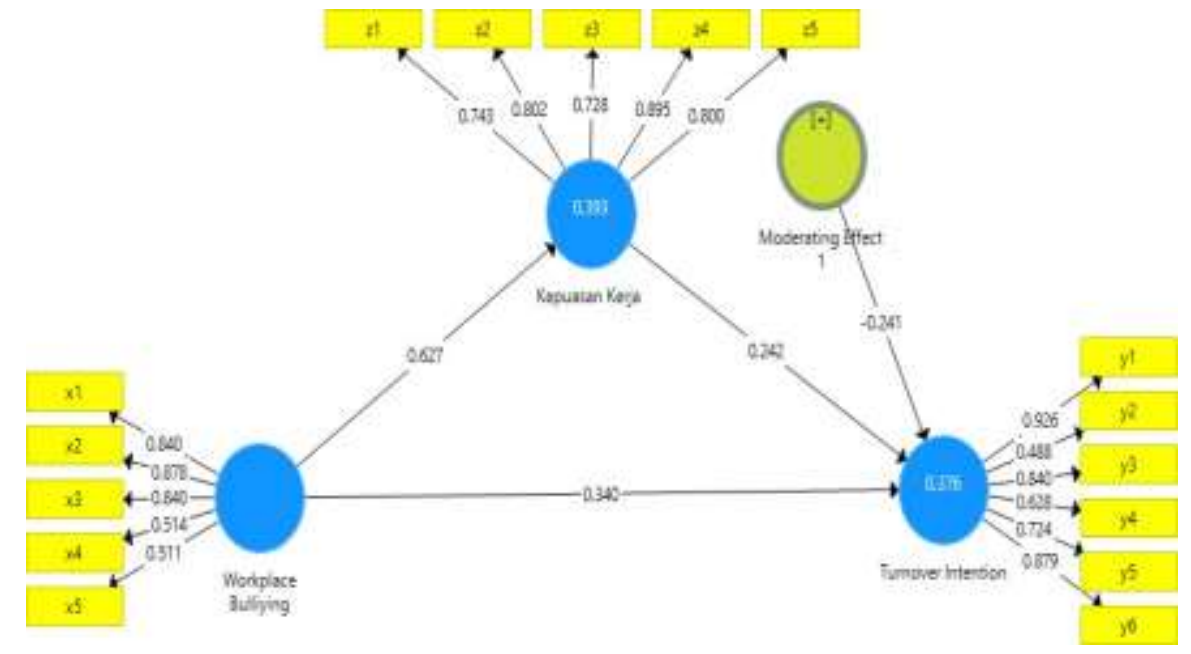

Figure 1. Structural Model 
Based on Figure 1 above, the R-Square value of the Job Satisfaction variable is $0.393 \%$, this value shows that the Job Satisfaction variable can be influenced by Workplace Bullying and Turnover Intention as much as $39.3 \%$ while the remaining $60.7 \%$ can be influenced by several other factors, namely variables that were not used in this study. Then the Turnover intention variable obtained an R-Square value of $0.376 \%$, which means that the Turnover intention variable can be influenced by Workplace Bullying by $37.6 \%$ and the remaining $62.4 \%$ is influenced by several other variables not included in this study.

Based on Figure 1 above, the R-Square value of the Job Satisfaction variable is $0.393 \%$, this value shows that the Job Satisfaction variable can be influenced by Workplace Bullying and Turnover Intention as much as $39.3 \%$ while the remaining $60.7 \%$ can be influenced by several other factors, namely variables that were not used in this study. Then the Turnover intention variable obtained an R-Square value of $0.376 \%$, which means that the Turnover intention variable can be influenced by Workplace Bullying by $37.6 \%$ and the remaining $62.4 \%$ is influenced by several other variables not included in this study.

\section{Hypothesis Test}

Table 1. Partial Test of Workplace Bullying and Turnover Intention

\begin{tabular}{lccccc}
\hline Variable & $\begin{array}{c}\text { Original } \\
\text { Sample } \\
(\mathbf{O})\end{array}$ & $\begin{array}{c}\text { Sample } \\
\text { Mean (M) }\end{array}$ & $\begin{array}{l}\text { Standard } \\
\text { Deviation } \\
\text { (STDEV) }\end{array}$ & $\begin{array}{l}\text { T-Statistics } \\
(\mid \mathbf{O} / \text { SDEV } \mid)\end{array}$ & P-Value \\
\hline $\begin{array}{l}\text { Workplace Bullying }-> \\
\text { Turnover intention }\end{array}$ & 0.492 & 0.539 & 0.134 & 3.678 & 0.000 \\
\hline
\end{tabular}

The results of the first hypothesis test, the effect of bullying at work on turnover intention shows a coefficient of $0.492, p$-value 0.000 , and t-statistic 3.678. The probability value of 0.000 is less than 0.05 and the t-statistic is 2.954 which is greater than the $t$-scale of 1.96. These results indicate that bullying in the workplace has a positive and significant effect on employee turnover intention. So, the alleged influence of Workplace Bullying on Turnover Intention is acceptable.

Table 2. Partial Test of Job Satisfaction, Workplace Bullying and Turnover Intention

\begin{tabular}{lccccc}
\hline Variable & $\begin{array}{c}\text { Original } \\
\text { Sample } \\
(\mathbf{O})\end{array}$ & $\begin{array}{c}\text { Sample } \\
\text { Mean (M) }\end{array}$ & $\begin{array}{l}\text { Standard } \\
\text { Deviation } \\
\text { (STDEV) }\end{array}$ & $\begin{array}{l}\text { T-Statistics } \\
(\mid \mathrm{O} / \text { SDEV|) }\end{array}$ & P-Value \\
$\begin{array}{l}\text { Workplace Bullying } \\
\begin{array}{l}\text { and Job Satisfaction }-> \\
\text { Turnover intention }\end{array}\end{array}$ & -0.241 & -0.24 & 0.169 & 1.429 & 0.154 \\
\hline
\end{tabular}

The results of hypothesis test, namely job satisfaction and increasing the effect of bullying in the workplace on employee turnover intention, the coefficient is -0.241 with a

226 Management and Economics Journal (MEC-J)

Vol 5 (3) December 2021 
p-value of 0.154 and a t-statistic of 1.429. The p-value of 0.154 is greater than 0.05 and the t-statistical 1.429 is smaller than the t-statistical 1.96. These results explain that job satisfaction does not increase the impact of workplace bullying on employee turnover intentions. Therefore, the premise that job satisfaction strengthens the effect of workplace bullying on employee turnover intentions has been rejected.

\section{DISCUSSION}

\section{Workplace Bullying and Turnover Intention}

Based on the results of the internal model, it is known that bullying at work has a significant effect on turnover intentions. Because the more bullying occurs in the workplace, the greater the intention to terminate the employee. Likewise, the lower the bullying in the workplace, the lower the company's turnover intention. The results of respondents' answers regarding research conducted on Amaris Hotel Surabaya staff indicate that there is a workplace where bullying occurs which leads to employee turnover or employee turnover intentions. The existence of pressure in the appearance and lifestyle of Amaris Surabaya employees is one of the causes of bullying in the workplace.

This study is in line with the research of Djamilah et al. (2012) and Fadlyanti (2017) which showed a positive and significant impact between bullying at work on relocation intentions. If there are more workplaces that bully, the intention to move will increase, and if there are fewer workplaces that intimidate, there will also be fewer intentions to move. In addition, these results are also in accordance with the research of Hendryadi \& Rachma (2018) which states that rudeness in the workplace is positively related to turning around. This shows that the amount of indecent behavior received by the employee will cause the magnitude of his intention to quit.

The effect of bullying in the workplace has a large and positive impact on employee turnover intentions, meaning that bullying in the workplace has become a major factor in the emergence of work stress among employees, and bullying targets have a greater tendency to leave. their jobs, threaten to leave, and often leave their jobs, than employees who have never been victims of bullying.

\section{Job satisfaction is not a moderating variable between workplace bullying and turnover intention.}

Looking at the results of the internal model, it was found that job satisfaction could not change the relationship between bullying at work and intention to turn around. These results indicate that job satisfaction does not increase the effect of workplace bullying on employee turnover intentions. Therefore, job satisfaction is not a factor that strengthens the relationship between workplace bullying and intention to turn back. The results of this study are different from what was stated by Locke (1976) in Sempane et al 
(2006) which found that satisfaction is a positive emotion resulting from employee evaluation and work experience. Job satisfaction can be measured through 4 dimensions, namely compensation, superior support, work environment and work safety. The results of this study, job satisfaction is interpreted as an uncomfortable emotional condition that makes employees not survive in a job, and uncomfortable emotions. states because of the environment, the employee's work is not good, or the employee is not satisfied with his job.

Based on the respondents' answers regarding questions to Amaris Hotel Surabaya employees, it was found that job satisfaction could not moderate the relationship between bullying at work and intention to turn back. Deviant behavior in the form of violation of individual privacy such as opening or responding to messages on cell phones without being asked by the co-workers concerned, and spreading gossip among employees which is intended to provide nurses who are victims of bullying at work feel uncomfortable in their environment. work environment, not to send information to colleagues that harm the First party, they are overly critical of their colleagues' performance even if they complete work according to job descriptions and refusal of responsibilities such as assigning tasks that are not job descriptions to other coworkers so that the purpose of bullying in the workplace looks bad to the boss or boss. This negative peer behavior is included in workplace bullying, Einarsen et al. (2009) in his research that bullying in the workplace can be in the form of individual bullying (personrelated bullying), bullying, and physical intimidation.

\section{CONCLUSION}

Based on the test results, it was found that bullying in the workplace has a significant effect on the intention to turn over. This indicates that the greater the bullying in the workplace, the higher the turnover intention will be. Likewise, the lower the bullying in the workplace, the lower the company's turnover intention.

The second test showed that job satisfaction could not change the relationship between workplace bullying and intention to turn over. These results indicate that job satisfaction cannot increase the effect of bullying at work on employee turnover intentions. Because job satisfaction is not a factor that can strengthen the relationship between bullying at work and turnover intention, this means that job satisfaction in the company cannot affect the desire to change employees due to cases of company bullying.

\section{REFERENCES}

Ahmad, Saima and Kaleem, Ahmad. (2019). Zooming in on the Workplace Bullying and Turnover intentions Pathway The Role of Well-Being and A Cultural Boundary Condition. Personnel Review. 49(2), 425-444. 
Bhat, M., Khan, S., and Rainayee Riyaz. (2020). Assessment of Perceived Labor Market Conditions in Employees' Turnover intention Model-Mediation and Moderation Analyzes. PSU Research Review. 2399-1747.

Djamilah, Siti, Dijah J, Iman K. (2012). The Effect of Bullying in the Workplace on Desire to Leave: Mediation Effects of Affective Organizational Commitment. Equilibrium, 10(2), 97-115.

Fadlyanti, Dian. (2017). Effect of Workplace Bullying on Intention to Switch With Strain as a Mediation Variable. Graduate program. Jakarta Open University

Hasibuan, Melayu, SP. (2007). Human Resource Management. Jakarta: Bumi Aksara

Hendyadi Dan Rachma Z. (2018). The Relationship between Workplace Incivility and Turnover Intention: The Moderating Effect of Gender. Journal of Feb Unmul.

Liang, H., and Yeh, Tsung-Kai. (2019). The Effects of Employee Voice on Workplace Bullying and Job Satisfaction. Management Decisions, 58(3), 569-582.

Memon, Mumtaz et al. (2020). Satisfaction Matters: The Relationships between HRM Practices, Work Engagement and Turnover Intention. International Journal of Manpower, 42(1), 21-50.

Miner, KN, Settles, IH, Pratt-Hyatt, JS, \& Brady, CC (2012). Experiencing Incivility in Organizations: The Buffering Effects of Emotional and Organizational Support. Journal of Applied Social Psychology, 42(2), 340t372. https://doi.org/10.1111/j.15591816.20110.00891.x

Nurul H and Idha R. (2014). Forms and Impact of Workplace Bullying on Factory Workers in Gresik. Journal of Psychoscience, 9(2).

Onyemah, V., Mulki J., Rivera, Martha. (2021). Salesperson Turnover intention: A Tale of Two Countries. 0265-2323.

Pawirosumarto, Suharno. Bachelor, Purwanto. and Gunawan Rachmad. (2016). The Effect of Work Environment Leadership Style and Organizational Culture Towards Job Satisfaction and Its Implication Towards Employee Performance in Parador Hotels and Resorts, Indonesia. International Journal of Law and Management, 29(6), 1337-1358.

Rai, A and Agarwal, U. (2017). Lingking Workplace Bullying and Work Engagement: The Mediating Role of Pychological Contract Violation. South Asian Journal of Human Resources Management, 4(1), 42-47.

Said KG And Irma S. (2019). The Influence of Work Overload and Intimidation on the Performance of Account Officer Employees of PT. Bank Aceh Syarih. Journal of Management and Innovation. 10(1), 22-35. 
Sani, Achmad (2013). Role of Procedural Justice, Organizational Commitment and Job Satisfaction on Job Performance: The Mediating Effects of Organizational Citizenship Behavior". International Journal of Business and Management, 8(15), 5767.

Sanjaya, K E. And Indrawati, A D. (2014). The Influence of Competence, Compensation and Work Environment on Employee Performance at PT Pande Agung Immediately Dewata. E-Journal of Management Udayana University, 3(1).

Sedarmayanti. (2017), Planning and Human Resource Development to Improve Competence, Performance, and Work Productivity. Bandung : PT Rafika Aditama.

Sempane, Me., Rieger, Hs., Roodt, G. (2002). Job Satisfaction in Relation to Organizational Culture. Sa Journal Of Industrial Psychology, 28(2), 23-30

Sims, Randi and Sun, Peng. (2011). Witnessing Workplace Bullying and The Chinese Manufacturing Employee. Journal of Managerial Psychology. 27(1), 9-25.

Shalini, Srivastava and Agarwal, Swati. (2020). Workplace Bullying and Intention to Leave: A Moderated Mediatin Model of Emotional Exhaustion and Supervisory Support. Employee Relations: The International Journal, 42(6), 1547-1563.

Srivastava, Shalini and Dey, Banasree. (2019). Workplace Bullying and Job Burnout A Moderated Mediation Model of Emotional Intelligence and Hardiness. International Journal of Organizational Analysis, 28(1), 183-204.

Supriyanto, Sani, Achmad and Masyhuri, Machfudz. (2010). Human Resource Research Methods. Malang: Uin Maliki Press

Toly, A. (2001). Analysis of Factors Affecting Turnover Intention in Public Accounting Firm Staff. Journal of Accounting and Finance 3(2), 102-105

Yahya et al. (2012). The Impact of Workplace Bullying on Workplace Performance. Aechives Des Sciences, 65(4), 18-28

ZainaL, Veithzal Rivai et al. (2014). Human Resource Management for Companies. Jakarta: PT Raja Grafindo Persada 